\title{
IIIT Intellectual Panels at the ISNA 49th Annual Convention
}

The International Institute of Islamic Thought (IIIT) organized a two-day series of intellectual panels at the Islamic Society of North America's (ISNA) 49th annual convention, held in Washington, DC over the Labor Day weekend. These events, hosted in the institute's hospitality suite on the main floor of the Washington Convention Center, took place during 1-2 September 2012. Recently published IIIT books and other selected Arabic and English publications, as well as special collections of the late Ismail Al Faruqi's works and many of Ali Mazrui's books, journal articles, and personal items, were also prominently displayed. At the beginning of each session, a documentary on IIIT and its goals was shown.

Session 1: Maqāṣid al-Sharī 'ah as Philosophy of Islamic Law. Jasser Auda (IIIT: 2008)

Dr. Jasser Auda (Center of Islamic Legislation and Ethics, Qatar Foundation) framed this session of Maqāșid al-Sharī 'ah as Philosophy of Islamic Law: A Systems Approach, by presenting two ideas. The first one is adopting a maqūșidi approach to the Shari'ah, meaning that the maqāșid would serve as its base and not as an outcome of it. According to him, this approach would give the maqāssid enormous flexibility when Muslims are faced with changing times and cultures. This would also involve the integration of form and essence. However, essence would have priority over form because it is the 
latter's purpose. He then discussed how the maqāssid were, and should remain, the basis of fiqh al-mu 'ämalät as regards the individual, community, policymaking, and other levels, contending that this would open many doors for Islam everywhere. In Muslim-minority situations, in fact, he claimed that this approach would allow Islam to expand as non-Muslims begin to see how logical it is. He reminded the audience that if those elements that make up the Shari'ah (e.g., justice, mercy, wisdom, and wellbeing) are not present, then it is not the Shari'ah, regardless of what people may state.

His second idea involves applying a systems approach to the Shari'ah. This approach, which is becoming increasingly popular, can now be found in every social and natural science and throughout the humanities. He broke this down into five ideas: (1) the cognitive nature of systems, (2) the holistic nature of systems that recognizes that the whole is more than the sum of its parts, (3) the system has to be self-renewing by being open to what comes from outside the Shari'ah, (4) multidimensionality (each verse/hadith must be studied as regards its social, historical, and other dimensions, which means that more ijtihäd must be undertaken), and (5) purposefulness (there is no action without an actor, no action without a purpose). He concluded his presentation here, saying that the rest of the book is an elaboration upon these and other ideas.

Discussant Ebrahim Rasool (Ambassador of South Africa to the United States) began his comments by citing the following hadith: "Those who stand in our way, we will show them the way." According to him, in the South African context of apartheid, those who sought change understood this to mean that if one struggles sincerely and with faith, the way will unfold. He stated that Auda's work represents an internalization of the maqașid and reminisced about how his contacts with IIIT over the years had benefitted him. He especially appreciated one example given in the book: how Muslims could reconstruct Islam if they were deprived of the chance to practice it. This actually happened in apartheid South Africa, which banned all Islamic activities and rituals for over a century and jailed and/or stripped offenders of their property. And yet in Nelson Mandela's first cabinet there were nine Muslim cabinet ministers, and he himself was appointed premier of the Western Cape Province (2004-08). How, he wondered, could such things happen, when all they had to work with was "What does Allah want of us here and now? If the Prophet were with us, what would he tell us to do?"

During the question and answer session, Rasool also asserted that the maqāsid explain why, not how, we worship. If we can implement them, we will be able to reclaim the life-force of Islam, which we have lost. Doing so 
will also allow Muslims and non-Muslims to grow closer together, which will be to everyone's benefit. If the maqāsid were adopted as the core of Arab Spring, they could even form the basis of a new Muslim civilization.

Session 2: The Concept of God in Judaic, Christian, and Islamic Traditions. Zulfiqar Ali Shah (IIIT: 2012)

Zulfiqar Ali Shah's (Islamic Society of Milwaukee) 727-page tome, Anthropomorphic Depictions of God: The Concept of God in Judaic, Christian, and Islamic Traditions: Representing the Unrepresentable, is the result of several decades of research into how depicting God in anthropomorphic and corporeal terms affects our understanding of His transcendence. According to Shah, the Old Testament states that man was "created in the image of God," which is understood in a physical, rather than a moral, sense. In his words, this brings about the following situation: Instead of trying to live a moral life, we search for a way to fit God into our political, national, and other agendas. An unfortunate side effect of this approach can be the denial of His existence because He cannot "fulfill" His "promises." Scholars have tried to give metaphorical interpretations and meanings to such Biblical accounts as the Hebrews' enslavement in Egypt and how God repents of creating humanity (Genesis 6:5-6), but the text supports none of them. The Old Testament, as well as the Kabbala and the Talmud, are full of anthropomorphism.

Christians claim that God most fully revealed Himself via His selfrevelation through Jesus. Given that Jesus was a man who lived a human life, Christians clearly have an anthropomorphic and corporeal image of God. This has led to many difficulties, such as the one encountered at the Council of Chalcedon (451), which declared Jesus to be "perfect man and perfect God" simultaneously. But if this is true, he asked, where does one draw the line between Jesus as God and Jesus as man? For instance, exactly who was crucified?

Islam, on the other hand, stresses God's transcendence in order to emphasize His unity. This makes it a truly universal religion. Yet the Qur'an does contain some anthropomorphic expressions, such as God's "face" (Q. 2:115) and "hand" (Q. 3:73), all of which have sparked widespread and long-standing discussions. The traditional answer has always been bila kayf(without how), so that no comparison can be made between God and man. The Qur'an is very clear on this.

Shah also asserted that the Old Testament's view of Yahweh as the "God of Israel" and His use of Joshua to exterminate the inhabitants of the "Promised land" was used by the Christian Europeans to justify their conquest of 
the Americas. As the "New World" was the new "Promised Land," both the removal, if not the outright extermination, of the indigenous inhabitants were Biblically justified. This attitude remains with us even today, as seen in the Israel/Palestine conflict.

In her response, Karen Armstrong remarked that the Bible and the Qur'an are different kinds of scriptures. The Mishna, the Talmud, and the New Testament, as well as the Manichee scriptures, are examples of God manifesting Himself in text. The Qur'an is, in fact, the best example of this type of revelation. Before Rome destroyed the Temple in $70 \mathrm{CE}$, Judaism was a "temple" religion. The surviving rabbis turned it into a "book" religion via the Midrash, which literally means "to go in search of something." This search was not restricted to the text on the grounds that the "word of God" cannot be tied down to one interpretation. In fact, Judaism's scriptures consist of a "library of sacred texts developed over a millennium," some of which the rabbis know are "very primitive."

She went on to say that God, who cannot reveal Himself totally, is involved in continual communication with humanity. For example, the Trinity "is not a doctrine, but was devised as a meditation for new [Christian] converts to remind them that you couldn't think about God as a single personality." Given that we can only see glimpses of Him in a person, for the eternal always escapes us, "when we speak of God we don't know what we're talking about." Until the Reformation, Christians understood that the Bible could not be taken literally. She closed by saying that Jesus is what God might be like if God came in a human form; however, Jesus is not God.

Muzammil Siddiqi (Fiqh Council of North America) pointed out that in the Arabic translation of the Old Testament, "God" is translated as "Allah" twenty-two times on the very first page of Genesis. According to him, the use of "Allah" is a modern problem. Although God is "beyond," and therefore neither this nor that, a relationship can be established with Him via His 99 Names. Yet one cannot discuss Him in the context of "how," for this would mean that one is trying to construct an image of Him. Siddiqi concluded that "Muslims have committed a lot of sins, but they have never made an image of God."

Joseph Montville (George Mason University) commented that Islam has stimulated a deeply engaged analysis of God in history. As the most liberal and libertarian Abrahamic faith, it has opened its arms wide to Judaism and Christianity. He also stated that a muslim, as distinct from a Muslim, is someone who submits to God and allows His grace to flow over him/her. Praising IIIT for its important contribution of requiring Jews and Christians to look at 
Islam and Islamic sources, he ended by saying that Islam sees Jews, Christians, and Muslims as family members in moral, cultural, and historical terms.

Section 3: Parent-Child Relations: A Guide to Raising Children. Hisham Altalib and Omar Altalib (IIIT: Forthcoming)

This book, part of a three-volume series on the topic of parenting by Hisham Altalib (IIIT) and Omar Altalib (Minaret of Freedom), is grounded on the famous hadith in which the Prophet said that people are like minerals when it comes to good and evil, just like minerals of gold and silver. Those who were best before Islam will continue to be the best after Islam, provided that they develop a thorough understanding of Islam.

They stressed several core topics that parents need to understand in order to raise devout children: (1) A person cannot learn how to be moral, honest, respectful of others, and so on by reading books or attending lectures later in life. Such values can only be formed while one is growing up and, under the guidance of his/her parents or other adults, learning how to implement them, seeing the consequences of doing or not doing something, and understanding the relevant relationships; (2) Parents need to be actively involved with their children, engage in family activities that will appeal to them, and be honest and truthful with them; (3) Parents must approach their children on the latter's level, which is often emotional, because they have not yet acquired the relevant skills of logic and rationality; (4) Children, who are far more observant than their parents, notice how their parents interact with each other, their own parents, and with others. They see who is favored, insulted, and ignored, and they act accordingly. As they have not yet fully developed their analytical skills, they may begin to see their parents as hypocrites and/or underserving of the respect they demand if their actions do not match their words.

As small religious/ethnic minorities in mainstream Christian/white European, and now largely secular, America, parents still confront the age-old issues of peer pressure, who has more influence on the child (viz., parents or friends), how to instill self-confidence and moral values, what to do with intrusive in-laws and relatives, and so on. The authors strongly encouraged those present not to "go to war" with their children, for they cannot "win." Rather, they should persuade their children to accept what they are saying; tell them about their ancestors so they can be proud of the people who produced them and their accomplishments; and spend quality time with them and make their friends feel comfortable. In addition, parents must work as a coherent team so the child cannot play one parent off against the other. 
The session concluded by advocating that since this advice and all of the other relevant parenting skills are neither inherent nor inherited, they should be taught in high school and even at the university level.

Session 4: The Arab Awakening: Islam and the Middle East. Tariq Ramadan (Oxford University Press: 2012)

In his latest book, The Arab Awakening: Islam and the Middle East, Tariq Ramadan (Oxford University) aired many of his ongoing concerns, among them the secular-religious dichotomy, the damaging Sunni-Shi'a division, the largely ignored relationship between economics and religion, and the need to choose one's words carefully. For example, what is the proper term for what is going on in the Middle East: revolution, spring, people power, uprising, people's movement? What do these terms actually mean? Do they imply certain goals and/or consequences? Are they being used to distract us from certain underlying trends?

He wondered if George W. Bush's assertion of "pushing democracy in the region" might have been no more than a recognition that change was coming and that Washington had to reposition itself to make the most of it. After all, the West had an active role in training and assisting the region's "cyber dissidents." After remarking that the Middle East has started to shift eastward, at least in economic terms, and that China has increased its presence in the region seven-fold in the last eight years, he raised more questions: Where is Muslim unity? Who is supporting the Salafis? Why have so many Islamists suddenly accepted capitalism and now call themselves capitalists? Is everyone an Islamist? Who, or what, is behind the very problematic alliances now being made? Why does the West have no problem with those Salafis who support the economic status quo? Given that political and economic change go together, as in Turkey under Prime Minister Erbakan, why are we not more focused on economics and religion? What exactly is secularism and how is it used? In the post-colonial era, what does din wa dawlah mean? What about dawlah madaniyah and dawlah islämìyah, terms that do not even exist in our heritage? What do we mean when we assert that ethics and politics cannot be separated, as is the case in the West? Can we even talk about Islamic democracy? What are the economic actors' social policies? What kind of education are they promoting? How do we formulate a true civil society? Why is Israel being so quiet? Why aren't we treating Syria like Egypt and Libya?

He concluded by advising Muslims to pay attention to Turkey, drop their obsession with the West (we are now living in a multipolar economic world), 
and bring forth their own culture of creativity and internal dynamism to move beyond the "culture of colonialism" in which they have become stuck.

Session 5: The State of Islamic Studies in American Universities. Mumtaz Ahmad, Zahid Bukhari, and Sulayman Nyang, eds. (IIIT: 2012)

The featured speakers addressed the Muslim community's need to focus on how Islam is being taught in American universities, especially after 9/11. Zahid Bukhari (Georgetown University) discussed the ongoing debate of whether Islam should be placed in Middle East area studies or Islamic studies. He opined that given Islam's vastness, the sheer difficulty of studying it requires the production of a standard textbook. Students and teachers of Islam need to establish relations with local Muslim communities and policymakers and to get involved in academic matters so that they can connect what they learn with the larger world. He cited the Jews, who for many years have funded foundations, philanthropic undertakings, and academic institutions in order to explain their religion and themselves, as well as to serve their neighbors, in their own words. Perhaps now, due to Arab Spring, Muslims will finally be able to speak for themselves.

Sulayman Nyang (Howard University) analyzed the history of teaching courses on Islam and Muslims in the United States: its European antecedents; the role of missionaries (e.g., establishing institutions of higher learning in Lebanon, Egypt, and Turkey); the rise of Orientalism; the introduction of Arabic into the academy (emphasis on religion); and how Islam became part of area studies (e.g., politics and related fields) during the cold war. He called upon Muslims to write their own critical narratives instead of just critiquing the Orientalists.

Discussant Imad-ad-Dean Ahmed (Minaret of Freedom) raised several questions: Can one know Islam without knowing Muslims? What about merging religious studies and area studies? What about starting with the Qur'an and bringing in the other material at a later date? How can we put cultural studies into the historical context to show how they have influenced world history? How did the Jews get the "right" to teach courses on Judaism, which was not always the case?

Discussant Ali Mazrui (SUNY Binghamton) recounted instances of being told by various university administrators to teach mainly classical- and medieval-era classes on Islam to avoid such "sensitive" issues as Israel, which any class on contemporary Islam would have to address. He urged Muslims to "liberate" Islam from such strictures. Although Islam cannot be "liberated" from Arabic, he pointed out that Islamic literature in Swahili, Farsi, Urdu, Malay, and Turkish exists and should be studied. 
Session 6: The Development of Islamic Legal Theory and the Objectives of the Shari 'ah: A Conversation with Taha Al Alwani (in Arabic). Zainab AlAlwani (IIIT: 2012)

In this publication, her latest book, Zainab Al-Alwani (Howard University; Fiqh Council of North America) seeks to find ways for American Muslim families to deal with contemporary issues, mainly related to family, that such traditional methodologies as ijtihād and the traditional maquassidi framework, including qiyās and other techniques, did not envision.

She interviewed her father, Shaykh Taha Jabir al-Alwani, to learn how he developed his methodology. In his capacity as a mujtahid, he argues with the scholars of $u s \underline{u} l$ about the role of intellect and reason. He states that the human intellect is to be used to understand revelation, which is both a source of knowledge and of rulings. Indeed, he has spent his career working to build a methodology of how to deal with the Sunnah, as well as the Islamic tradition, in the fields of fiqh and other literature.

The Qur'an is the primary source for knowledge and rulings, while the Sunnah is its explanation (bayān). Given this, the latter should be studied in light of the former and in the context of the Prophet's time and place. Scholars should focus on the Qur'anic language and approach the Qur'anic text as a unit, a text that can "explain itself by itself." Thus, one cannot base a ruling on a single verse, because such an undertaking cannot possibly provide a comprehensive answer to one's question. Contemporary scholars must identify the underlying cause ( 'illah) and then determine why and how that particular ruling was devised. According to him, many scholars have limited their focus to a particular issue. In addition, they should read the Sunnah within the Qur'an, given that Muhammad was "the walking Qur'an.” In other words, the two cannot be separated.

Shaykh Taha has divided the reading of the Qur'an into three levels: (1) tawhìd (Divine unity), tazkiyah (purification), and 'umrān (civilization; the relationship between the Creator, the creation, and the created [humanity]); (2) the tradition; and (3) the traditional way of understanding many concepts

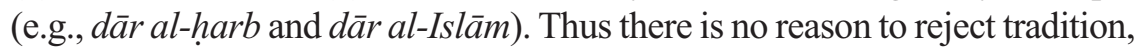
for it is a matter of which level best addresses a specific question. In his words, Muslims need to ask more questions and stop demanding immediate answers. They must consult social scientists and other experts, not just jurists, in order to acquire an accurate understanding of what these issues mean in contemporary American society.

Shah opined that the traditional meaning of qiyass may not be adequate today because it is so hard to find the underlying cause. Thus it has remained largely theoretical. According to him, the Muslims' present minority context 
and colonialism made them aware of their three-century-long intellectual stagnation and bankruptcy. During that time, the element of 'umrān was missing because Muslims were not in control of their own civilization. In addition, he raised several important issues. For example, who is qualified to define the maqāsid? Yet there is a danger to this approach, he contends, for if one challenges hadiths that have been authenticated by al-Bukhari, Muslim, and others, as Shaykh Taha has done, where does one draw the line? Such a "dangerous approach" can undermine the Islamic heritage. He called upon Muslim religious scholars to study the Qur'an in o rder to find new meanings, rather than to impose their own ideas upon it.

Jamal Barzinji (IIIT) credited Shaykh Taha with introducing two new insights: the first that Qur'an vetoes the Sunnah, and the second that Sunnah has to be subjected to the time/space dimension. Both of these are crucial to reforming Islamic thought.

Jay Willoughby

AJISS

Herndon, VA 